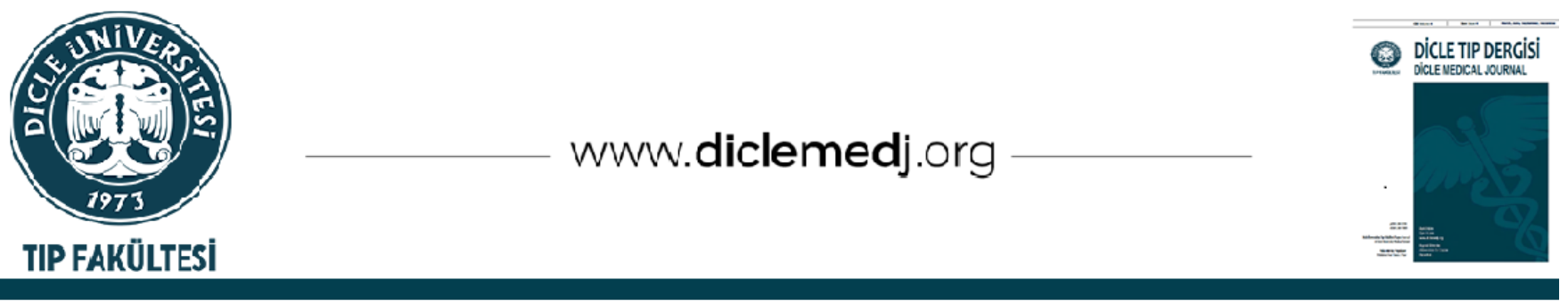

Original Article / Özgün Araştırma

\title{
Apoptotic and Anti-inflammatory Effects of Hypericum Perforatum Extract in Human Basal Cell Carcinoma TE 354.T Cell Line
}

\author{
Ebru Celik ${ }^{D_{1}}$, Halil Mahir Kaplan ${ }^{D_{2}}$, Ergin Singirik ${ }^{D_{2}}$, Muhammed Salih Celik ${ }^{D_{3}}$, Harun Alp ${ }^{D_{4}}$ \\ 1 Department of Dermatology, Faculty of Medicine, Hatay Mustafa Kemal University, Hatay, Turkey
}

2 Department of Pharmacology, Faculty of Medicine, Cukurova University, Adana, Turkey

3 Faculty of Medicine, Hatay Mustafa Kemal University, Hatay, Turkey

4 Department of Pharmacology, Faculty of Medicine, Hatay Mustafa Kemal University, Hatay, Turkey

Received: 12.01.2021; Revised: 25.02.2021; Accepted: 26.02.2021

\begin{abstract}
Objectives: Basal cell carcinoma is the most common malignancy in in the Caucasian race and is a serious health problem with its ever-increasing incidence and high cost. Although the treatment is surgical, some elderly patients do not accept surgical intervention. In this case, non-surgical treatments come into prominence. The Hypericum perforatum (HP) / St. John's Wort plant has been used in the treatment of many diseases for centuries among local people. Here, we aimed to aimed to elucidate the effect and molecular mechanism of the HP plant on BCC cells.

Methods: Human BCC cell lines TE 354.T were acquired from ATCC ${ }^{\circledR}$, then were cultured in Dulbecco's Modified Eagle's Medium. BCC cells were seeded at a concentration of $2 \times 106$ cells in each flask $(n=12)$. After incubation, while six of the flasks were applied with a $0.8 \% \mathrm{HP}$ extract and $99.2 \%$ medium for 48 hours, no application was made to the control group. The effects of HP on mitochondrial mediated intrinsic and extrinsic apoptotic pathway agents, cell cycle G2 / M checkpoint kinases and inflammatory mediators were investigated in BCC cancer cells. The expression and activities of these mediators in both groups were evaluated by ELISA test.
\end{abstract}

Results: It was determined that HP extract treatment increased the expression of apoptotic proteins (AIF, GADD153, GRP78, caspase-3, Bax) and cell cycle G2 / M checkpoint kinase (Wee1), though it reduced antiapoptotic protein (Bcl-2) and inflammatory mediators (iNOS, COX-2, cPLA2, NFkB) in BCC cell lines.

Conclusion: HP extract can support routine chemotherapy on BCC cells with its apoptotic, anti-inflammatory and anti-cancer effect, and may be a beacon of hope in reducing resistance to chemotherapeutic drugs in the treatment of BCC.

Keyword: Hypericum perforatum; St. John's wort; Human basal cell carcinoma; Apoptotic; Anti-inflammatory effect.

DOI: 10.5798/dicletip.887378

Correspondence / Yazışma Adresi: Ebru Celik, Department of Dermatology, Faculty of Medicine, Hatay Mustafa Kemal University, Hatay, Turkey e-mail: ebruecelik@yahoo.com 


\section{İnsan Bazal Hücreli Karsinom TE 354.T Hücre Hattında Hypericum Perforatum Ekstraktının Apoptotik ve Antiinflamatuvar Etkileri}

Öz

Amaç: Bazal hücreli karsinom (BHK), beyaz ırkta en sık görülen malignitedir ve sürekli artan insidansı ve yüksek maliyeti ile ciddi bir sağlık problemidir. Tedavisi cerrahi olsa da bazı yaşlı hastalar cerrahi müdahaleyi kabul etmemektedirler. Bu durumda ameliyatsız tedaviler ön plana çıkmaktadır. Hypericum perforatum (HP)/ Sarı Kantaron bitkisi halk arasında yüzyıllardır pek çok hastalığın tedavisinde kullanılmaktadır. Bu çalışmada, HP bitkisinin insan BCC hücreleri üzerindeki etkisinin ve moleküler mekanizmasının aydınlatılması amaçlanmıştır.

Yöntemler: İnsan BHK hücre hatları TE 354.T, ATCC ${ }^{\circledR}$ 'den elde edildi. Daha sonra Dulbecco Modifiye Eagle ortamında kültive edildi. BHK hücreleri, her bir flaskta $(n=12) 2 \times 106$ hücre konsantrasyonunda üretildi. İnkübasyondan sonra, flasklardan 6 'sına 48 saat boyunca \%0.8 HP ekstresi ve \% 99.2 medyum ile uygulanırken, kontrol grubuna herhangi bir uygulama yapılmadı. HP'nin BHK kanser hücrelerinde mitokondriyal aracılı intrinsik ve ekstrinsik apoptotik yolak ajanları, hücre döngüsü G2 / M kontrol noktası kinaz ve inflamatuar mediyatörler üzerindeki etkileri araştırıldı. Her iki gruptaki mediatörlerin ekspresyonu ve aktiviteleri ELISA testi ile değerlendirildi.

Bulgular: HP ekstresi tedavisinin BHK hücre hatlarında, apoptotik proteinlerin (AIF, GADD153, GRP78, kaspaz-3, Bax) ve hücre döngüsü G2 / M kontrol noktası kinazının (Wee1) ekspresyonunu arttırdığı, buna karşılık antiapoptotik proteini (Bcl-2) ve inflamatuar mediatörleri (iNOS, COX-2, cPLA2, NFkB) azalttı̆̆ı belirlendi.

Sonuç: HP ekstresi, apoptotik, antiinflamatuvar ve anti-kanser etkisi ile BHK'da rutin kemoterapiyi destekleyebilir ve BHK tedavisinde kemoterapötik ilaçlara direnci azaltmada bir umut ıșığı olabilir.

Anahtar kelimeler: Hypericum perforatum; Sarı Kantaron; Insan bazal hücre karsinomu; Apoptotik; Anti-inflamatuar etki.

\section{INTRODUCTION}

Basal cell carcinoma is the most common malignancy in in the Caucasian race. The American Cancer Society reports that 8 out of 10 skin cancers are diagnosed as BCC. Treatment is usually provided through surgical intervention, however, for BCC, when the operation is not possible, a nonsurgical approach is considered. In this case, in addition to medical treatment, alternative and complementary treatments come into prominence $^{1}$.

Hypericum perforatum (HP)/ St. John's wort is a plant that has been used by humans for the treatment of various diseases for centuries. Hypericin, pseudohypericin, hyperforin, adhyperforin, hyperoside, quercetin, quercitrin, isoquercitrin, rutin, kaempferol, biapigenin and chlorogenic acid which are the main ingredients in plant extract, are important active compounds ${ }^{2,3}$. Studies have shown that some of the active ingredients contained in HP affect apoptosis in the cell4. It has been reported that apigenin induces Bax (proapoptotic Bcl-2-associated X protein) and $\mathrm{Bcl}-2$ (B-cell lymphoma 2) in lung cancer line cell, leading to apoptosis5. Apoptotic pathways are important in terms of cancer evolution and chemotherapeutic resistance ${ }^{6,7}$. There are studies showing that agents regulating apoptotic pathways may provide a treatment option in cancer8. On the other hand, hypericin and hyperforin have been shown to reduce inflammatory prostaglandin E2 and COX-2 (cyclooxygenase-2) release from activated macrophages. It is reported that hypericin and hyperforin can be potential target drugs in cancer treatment due to their anti-inflammatory effect ${ }^{9}$.

In our study, the impact of HP extract on BCC cells and mediators of apoptotic pathways was investigated. In BCC cells incubated with HP extract, the expression profile of AIF (apoptosisinducing factor), GADD153 (growth arrest and DNA damage 153), grp78 (glucose-regulated 
protein 78), caspase-3, Bax, Bcl-2 and cell cycle G2 / $M$ checkpoint kinase Wee 1 and also inflammation mediators as iNOS (inducible nitric oxide synthase), COX-2, CPLA2 (cytosolic Phospholipase A2), NFkB (Nuclear Factor kappa B) was examined and compared with the control group.

\section{METHODS}

This study was carried out between June 26th, 2018 and November 15th, 2018 in the laboratory of Department of Pharmacology, Faculty of Medicine, Cukurova University, Turkey. No ethical approval was required for the cell line study, which complied with all relevant regulations.

\section{Preparation of HP extract}

HP was harvested in Pozantı city in Turkey in July. The aboveground parts (flowers, leaves and stem) were desiccated in the incubator at 24 hours. The desiccated portions were pulverized in a blender. This powder ( $40 \mathrm{~g}$ ) was extracted by holding in a mixer overnight in $100 \mathrm{ml}$ of $80 \%$ ethyl alcohol solution and then filtered with filter paper. The alcohol in the solution was evaporated by using rotary evaporator (IKA RV 10 basic, IKA company, Germany) in vacuo at $700 \mathrm{C}$ with minor modifications as defined previously ${ }^{10}$. Thus, the extract was obtained in the form of dry powder. HP extract was prepared in $0.8 \%$ concentration for experiments using Dulbecco's modification of Eagle's medium (DMEM) (GIBCO) ${ }^{11}$.

\section{Cell culture}

The human BCC cell line TE 354.T (CRL-772TM) was obtained from American Type Culture Collection (ATCC ${ }^{\circledR}$ ). BCC cells were grown on fetal bovine serum (Hyclone), 1\% L-Glutamine (Hyclone), 1\% Penicillinstreptomycin (Hyclone) and DMEM.

\section{Cell viability test}

The cytotoxicity of the extract was determined by measuring dark blue formazan production in living cells using MTT (3-(4,5-dimethyl-2-thiazolyl)-2,5- diphenyl tetrazolium bromide, Sigma)12. Stock solution at $5 \mathrm{mg} / \mathrm{ml}$ concentration was prepared by dissolving MTT in phosphate buffered saline (PBS). BCC cells were seeded in 96-wells at a concentration of $1 \times 104$ cells in each well and kept overnight. It was incubated for 48 hours with $0.8 \%$ HP extract. Then, the MTT solution was added at a concentration of $0.5 \mathrm{mg} / \mathrm{ml}$ and kept at $37^{\circ} \mathrm{C}$ for 2 hours. Supernatants were elaborately separated and $200 \mu$ DMSO (Sigma-Aldrich) was added to form the formazan crystals. The amount of formazan was measured using a plate in a $570 \mathrm{~nm}$ wavelength UV spectrophotometer (Rayto Life and Analytical Sciences, China).

\section{Extract application and cell homogenization}

BCC cells were seeded in $75 \mathrm{~cm} 2$ flasks at a concentration of $2 \times 106$ cells in each flask $(n=12)$. After incubation at $37^{\circ} \mathrm{C}$ in $5 \%$ of $\mathrm{CO} 2$ environment, while six of the flasks were applied with a $0.8 \%$ HP extract and $99.2 \%$ medium for 48 hours, no application was made to the control group.

Cells were then washed with PBS and lysates were prepared on ice with RIPA Lysis Buffer (89900, Thermo Scientific) within fifteen minutes. It was centrifuged at $15000 \mathrm{rpm}$ for twenty minutes. Resulting supernatants were taken into tubes and pellets were discarded. These supernatants were then used in the ELISA test.

\section{Determination of protein amount}

The amount of protein was measured using the ELISA test. The total amount of protein in homogenized cells was determined by the Bradford method13. Bovine serum albumin and seven diluted standard solutions $(1,2,3,5,7,8$ and $10 \mu \mathrm{g} / \mathrm{ml}$ ) were prepared to compose a standard curve to compare the protein concentrations in the samples to be measured. 10 $\mu \mathrm{l}$ of each sample was taken and distilled water was added until the total volume reached $100 \mu \mathrm{l}$. $1 \mu \mathrm{l}$ of Bradford solution was added to each 
standard and sample, then mixed using a vortex. Protein amounts were then measured at $595 \mathrm{~nm}$ by using a spectrophotometer (Rayto Life Reader, China). Protein concentrations were measured against standard solutions in $\mu \mathrm{g} / \mu \mathrm{l}$ and shown in the Prism program (GraphPad Software, USA).

\section{ELISA test}

Quantifications of AIF, GADD153, GRP78, Bax, cleaved caspase-3, Bcl-2, Wee 1, iNOS, COX-2, CPLA2 and NFkB proteins was carried out according to the manufacturer's instructions using ELISA kits obtained from Shenzhen Genesis Technology (Guangdong, China).

\section{Statistical Analysis}

The protein level results obtained from the BCC cell line with HP extract were determined as the HP treated group. The protein level results obtained from BCC cell line without HP were evaluated as the control group. Data were analyzed using $\mathrm{R}$ programming version 4.0.2. Unpaired Student's t test was used to compare parameters in the control and HP treated groups. All data were shown as "mean values \pm standard deviation" and a $p$ value of $<0.05$ was considered statistically significant.

\section{RESULTS}

Compared to the HP treated BCC cell culture line and the control group, in the group receiving HP treatment, it was determined that the amount of AIF, GADD153, GRP78, Bax, cleaved caspase-3, which has a role in the apoptotic pathway, were increased, as well as the cell cycle G2 / M checkpoint kinase protein Wee 1 was found to increase. The AIF, GADD153, GRP78, cleaved caspase-3, Bax and Wee 1 results of the HP treated group and the control group are expressed as mean \pm standard deviation as shown in Table I.
Table I: The effect of Hypericum perforatum extract on apoptosis and cell cycle G2/M checkpoint kinase on human basal cell carcinoma cell lines.

\begin{tabular}{|lcccc|}
\hline & Control & HP treated & t & p \\
\hline AIF & $0.683 \pm 0.052 \mathrm{pg} / \mathrm{ml}$ & $1.703 \pm 0.220 \mathrm{pg} / \mathrm{ml}^{*}$ & 33.81 & $<0.001$ \\
GADD153 & $0.188 \pm 0.038 \mathrm{pg} / \mathrm{ml}$ & $2.193 \pm 0.612 \mathrm{pg} / \mathrm{ml} *$ & 10.34 & $<0.001$ \\
GRP78 & $0.480 \pm 0.063 \mathrm{pg} / \mathrm{ml}$ & $4.543 \pm 0.816 \mathrm{pg} / \mathrm{ml} *$ & 15.69 & $<0.001$ \\
Caspase-3 & $0.476 \pm 0.419 \mathrm{pg} / \mathrm{ml}$ & $3.400 \pm 1.380 \mathrm{pg} / \mathrm{ml}^{*}$ & 6.411 & $<0.001$ \\
Bax & $0.772 \pm 0.310 \mathrm{pg} / \mathrm{ml}$ & $5.057 \pm 2.844 \mathrm{pg} / \mathrm{ml}^{*}$ & 4.736 & $<0.001$ \\
Wee 1 & $0.336 \pm 0.028 \mathrm{pg} / \mathrm{ml}$ & $0.980 \pm 0.080 \mathrm{pg} / \mathrm{ml} *$ & 24.03 & $<0.001$ \\
\hline
\end{tabular}

HP: Hypericum perforatum, Wee 1: Cell cycle G2/M checkpoint kinase, AIF: Apoptosis-inducing factor, gadd153: Growth arrest and DNA damage 153, grp78: Glucose-regulated protein 78, Bax: Proapoptotic Bcl-2-associated $X$ protein.

Results are presented as mean $\pm S D$. Statistical analysis: Student $t$ test (*: For control $p<0.05$ ).

However, it was determined that Bcl-2 expression, which is an antiapoptotic protein, decreased. The levels of inflammatory mediators iNOS, COX-2, CPLA2 and NFkB were also decreased. Moreover, $\mathrm{HP}$ treatment has been observed to reduce the viability of human BCC cells. All the findings were found statistically significant $(p<0.05)$. The control group and the HP treated group results are expressed as mean \pm standard deviation as $\mathrm{Bcl}-2$, iNOS, COX-2, CPLA2, NFkB levels are presented in Table II. The schematic drawing of the effects of HP on BCC cell is shown in Figure 1.

Table II: The effect of Hypericum perforatum extract on antiapoptotisis and inflammation on human basal cell carcinoma cell lines.

\begin{tabular}{|lcccc|}
\hline & Control & HP treated & t & p \\
\hline Bcl-2 & $10.48 \pm 2.550 \mathrm{pg} / \mathrm{ml}$ & $5.250 \pm 3.273 \mathrm{pg} / \mathrm{ml}^{*}$ & 3.986 & 0.002 \\
iNOS & $1858 \pm 470.5 \mathrm{IU} / \mathrm{ml}$ & $1358 \pm 226.8 \mathrm{IU} / \mathrm{ml}^{*}$ & 3.027 & 0.004 \\
COX-2 & $5904 \pm 1697 \mathrm{pg} / \mathrm{ml}$ & $3906 \pm 1192 \mathrm{pg} / \mathrm{ml}^{*}$ & 3.046 & 0.025 \\
CPLA2 & $6717 \pm 673.5 \mathrm{pg} / \mathrm{ml}$ & $5600 \pm 451.7 \mathrm{pg} / \mathrm{ml}^{*}$ & 4.355 & $<0.001$ \\
NFkB & $8.267 \pm 1.705 \mathrm{ng} / \mathrm{ml}$ & $6.000 \pm 0.894 \mathrm{ng} / \mathrm{ml}^{*}$ & 3.723 & 0.003 \\
\hline
\end{tabular}

HP: Hypericum Perforatum, Bcl-2: B-cell lymphoma 2, iNOS: Inducible nitric oxide synthase, COX-2: Cyclooxygenase-2, cPLA2: Cytosolic Phospholipase A2, NFkB: Nuclear Factor kappa B.

Results are presented as mean $\pm S D$. Statistical analysis: Student $t$ test $\left(^{*}\right.$ : For control $p<0.05$ ). 


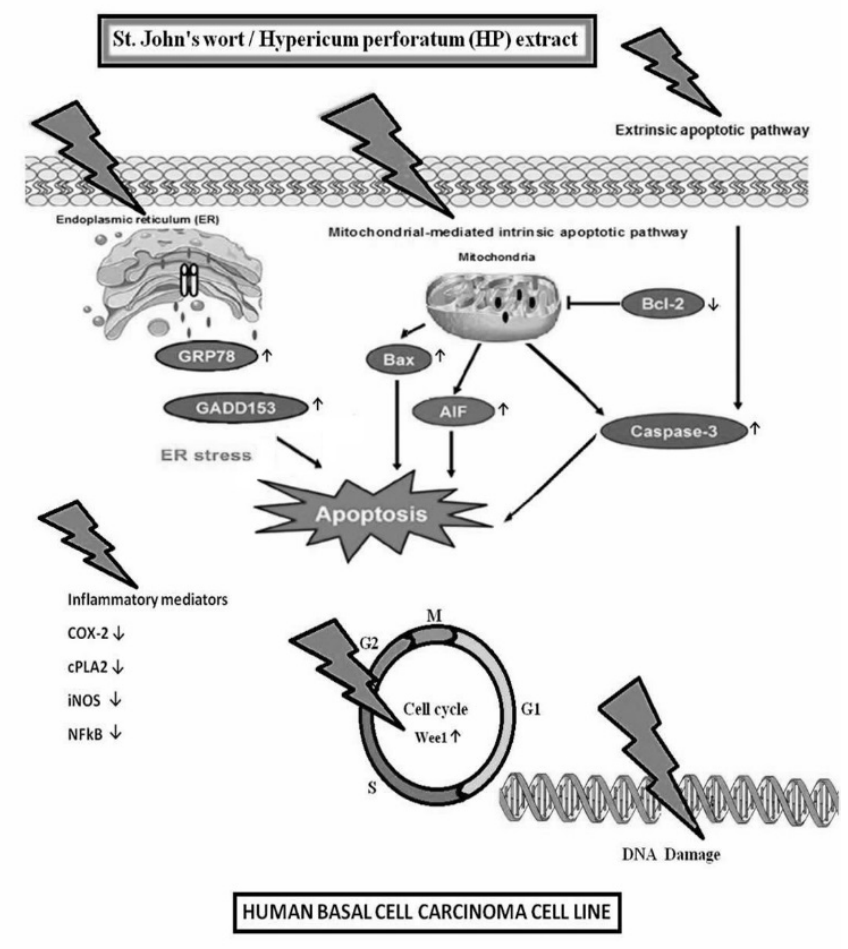

Figure 1. Hypericum perforatum/ St. John's wort extract affects mitocondrial-mediated intrinsic apoptotic pathway and extrinsic apoptotic pathway mediators, cell cycle G2/M checkpoint kinase and inflammatory mediators. It causes anti-inflammatory effects, apoptosis and DNA damage in human basal cell carcinoma cells.

\section{DISCUSSION}

BCC, a non-melanoma skin cancer, can generally be successfully treated with surgical excision ${ }^{1}$. However, a number of patients do not accept surgical intervention. In this case, non-surgical treatments come into prominence. In recent years, the cellular effects of plants used by the public on different types of cancer have been the subject of research ${ }^{14}$. Hypericum perforatum has biologically active ingredients such as hyperic ${ }^{3}$ and it is frequently used by the public in the treatment of various diseases ${ }^{2}$. More importantly, HP extract is known to affect apoptosis ${ }^{4}$ and is therefore chosen as the material of our study.

Apoptosis is a multi-step process that plays an important role in managing cell quantity and proliferation as part of normal progress. Apoptosis occurs spontaneously in malignant tumors and causes a decrease in tumor growth. Apoptotic pathways are extremely important in terms of chemotherapeutic resistance and cancer development and prognosis ${ }^{6-8,15}$. Furthermore, anti-inflammatory agents have been determined to have anti-cancer target effects through the impact on iNOS, COX-2, cPLA2, NFkB etc. ${ }^{16-18}$.

$\mathrm{Bcl}-2$ is a protein family mainly related to the outer membrane of mitochondria and it has both proapoptotic (Bax) and antiapoptotic (Bcl-2) members. Caspase, is a protease family connected with extrinsic and intrinsic pathway, which is the mitochondrial pathway. Activated caspase-3 causes apoptosis and DNA fragmentation. When the cell is damaged through Bax, apoptosis gains resistance ${ }^{19}$. Wee 1 protein plays a role in cell division and increases cell apoptotic stimulation and stops cell division in $\mathrm{G} 2 / \mathrm{M}$ phase. AIF which is another protein leads the cell to apoptosis by causing DNA damage by apoptotic stimulation. GADD153 protein is released from the endoplasmic reticulum in stress situations and causes DNA damage. GRP78 protein is located in the lumen of the endoplasmic reticulum and its amount increases and participates in apoptosis through apoptotic stimulation ${ }^{20}$.

It has been demonstrated in several studies that hypericin has antitumoral activity, which is one of the active components of the HP that we use in our study. It is believed that hypericin destroys tumor cells through both apoptosis and necrosis. The antitumoral effect of hypericin has been studied in melanoma, breast, colon, glioma, prostate, pituitary, nasopharyngeal, oesophagus cancers in vivo and in vitro, and its mechanism of action has been investigated ${ }^{4,11,21}$. Apigenin, a component of HP, has been shown to stop the cell cycle in many human cancer cell lines and induce apoptosis by activating both intrinsic and extrinsic apoptotic pathways of apoptosis ${ }^{5}$. Hyperforin, another substance in the composition of St. John's wort, increased apoptosis by causing caspase- 3 
activation and bcl-2 protein expression inhibition in human myeloid cancer cells ${ }^{22}$.

When we look at the studies of the HP extract on apoptosis, Martarelli et al. ${ }^{23}$, emphasized that the HP causes a significant decrease in tumor growth and metastasis, and stated that this natural compound may be useful in the treatment of prostate cancer. In another study, HP has been reported to modulate apoptosis in splenic lymphocytes of mice given in two doses $(30 \mathrm{mg}$ and $100 \mathrm{mg}$ ) per day and partially decrease Fas-Ag expression and partially increase bcl-2 expression ${ }^{24}$. In a study by Jang et al. ${ }^{25}$, St. John's wort has been shown to have a protective effect against $\mathrm{H} 2 \mathrm{O} 2$-induced apoptosis in human neuroblastoma cells. Yegani et al. ${ }^{26}$ evaluated the proapoptotic effect of HP extract in human colorectal adenocarcinoma cell line HT29. They detected that the $\mathrm{Bcl}-2$ was significantly decreased and the Bax, cleaved-caspase 3, Wee1, GRP78, GADD153 and AIF were significantly increased in $0.8 \%$ concentration $\mathrm{HP}$ extract treated human colorectal adenocarcinoma cell line. Similarly in our study, when the BCC cell culture line was compared with the control group, it was observed that the levels of AIF, GADD153, GRP78, Bax, cleaved-caspase-3, which were assigned in the apoptotic pathway, and Wee 1 protein increased in the HP treated group. However, it was determined that $\mathrm{Bcl}-2$ expression, which is an antiapoptotic protein, decreased; iNOS, COX-2, cPLA2, NFkB protein levels, which are inflammatory mediators, decreased as well.

\section{CONCLUSION}

The results of this study are expected to help elucidate the molecular mechanism of the HP plant's apoptotic and anti-inflammatory effects on non-melanoma skin cancer BCC cells. In our study, it was determined that HP extract induces apoptosis, reduces the level of mediators in the antiapoptotic pathway, and is also able to reduce inflammation, which is important in the development of cancer. Due to the detection of anti-cancer and anti-inflammatory effects of HP extract in human BCC cells, in treatment, it has been assumed that it may be a supportive agent for chemotherapeutics used routinely and reducing resistance formation. As a result, it has been concluded that HP extract, which has an impact on the BCC cell line, may be an effective agent in the treatment of BCC and that in-vivo studies are needed.

Acknowledgement: This study was supported by the Hatay Mustafa Kemal University Scientific Projects Coordination Unit (Project No: 17M 002).

Ethical Committee Approval: No ethical approval was required for the cell line study, which complied with all relevant regulations.

Declaration of Conflicting Interests: The authors declare that they have no conflict of interest.

Financial Disclosure: No financial support was received.

\section{REFERENCES}

1. Kim DP, Kus KJB, Ruiz E. Basal Cell Carcinoma Review. Hematol Oncol Clin North Am. 2019; 33: 13-24.

2. Patočka J. The chemistry, pharmacology, and toxicology of the biologically active constituents of the herb Hypericum perforatum L. J Appl Biomed. 2003; 1: 61-70.

3. Hışı Y, Şahin F, Omay SB. Composition of Hypericum perforatum L. and its medical importance. Int J Hematol Oncol. 2005; 15: 212-8.

4. Colasanti A, Kisslinger A, Liuzzi R, et al. Hypericin Photosensitization of Tumor and Metastatic Cell Lines of Human Prostate. J Photochem Photobiol B. 2000; 54: 103-7.

5. Lu HF, Chie YJ, Yang MS, et al. Apigenin Induces Caspase-Dependent Apoptosis in Human Lung Cancer A549 Cells Through Bax- And Bcl-2-triggered Mitochondrial Pathway. Int J Oncol. 2010; 36: 147784. 
6. Pistritto G, Trisciuoglio D, Ceci C, Gafuri A, D’Orazi G. Apoptosis as anticancer mechanism: function and dysfunction of its modulators and targeted therapeutic strategies. Aging (Albany NY). 2016; 8: 603-19.

7. Alimbetov D, Askarova S, Umbayev B, Davis T, Kipling D. Pharmacological Targeting of Cell Cycle, Apoptotic and Cell Adhesion Signaling Pathways Implicated in Chemoresistance of Cancer Cells. Int J Mol Sci. 2018; 19: 1690.

8. Kim C, Kim B. Anti-Cancer Natural Products and Their Bioactive Compounds Inducing ER Stress-Mediated Apoptosis: A Review. Nutrients. 2018; 10: 1021.

9. Berköz M, Allahverdiyev O, Yıldırım M. Investigation of the effect of hyperforin and hypericin on inflammatory response in RAW 264.7 macrophages. Van Med J. 2018; 25: 124-31.

10. Orhan IE, Kartal M. LC-DAD-MS-assisted quantification of marker compounds in Hypericum perforatum L. (St. John's wort) and its antioxidant activity. Turk J Pharmaceut Sci. 2015; 12: 279-86.

11. Ferguson A, Morris C, Curley J. Hypericum perforatum Extracts and Hypericin Treatment of a Mouse Mammary Cancer Cell Line Induces Growth Inhibition in a Dose Dependent Manner. J Exp Second Sci. 2012; 1: 14-8.

12. Mosmann T. Rapid colorometric assay for cellular growth and survival: Application to proliferation and cytotoxicity assays. J Immunol Methods. 1983; 65: 5563.

13. Bradford MM. A rapid and sensitive method for the quantitation of microgram quantities of protein utilizing the principle of protein-dye binding. Anal Biochem. 1976; 72: 248-54.

14. Yildirim IH, Azzawri AA, Duran T. Thymoquinone induces apoptosis via targeting the Bax/BAD and $\mathrm{Bcl}-2$ pathway in breast cancer cells. Dicle Med J. 2019; 46: 411-7.

15. Wong RS. Apoptosis in cancer: from pathogenesis to treatment. J Exp Clin Cancer Res. 2011; 30: 87.

16. Hashemi Goradel N, Najafi M, Salehi E, Farhood B, Mortezaee K. Cyclooxygenase-2 in cancer: A review. J Cell Physiol. 2019; 234: 5683-99.
17. Niknami $M$, Patel $M$, Witting PK, Dong Q. Molecules in focus: cytosolic phospholipase A2-alpha. Int J Biochem Cell Biol. 2009; 41: 994-7.

18. Todoric J, Antonucci L, Karin M. Targeting Inflammation in Cancer Prevention and Therapy. Cancer Prev Res (Phila). 2016; 9: 895-905.

19. Yazıcı P, Alizadehshargh S, Güner Akdoğan G. Apoptosis: Regulatory Molecules, Its Relationship with Diseases and Apoptosis Detection Methods: Review. Turkiye Klinikleri J Med Sci. 2009; 29: 1677-86.

20. Kale J, Osterlund EJ, Andrews DW. BCL-2 family proteins: changing partners in the dance towards death. Cell Death Differ. 2018; 25: 65-80.

21. Kleemann B, Loos B, Scriba TJ, Lang D, Davids LM. St John's Wort (Hypericum perforatum L.) Photomedicine: Hypericin-Photodynamic Therapy Induces Metastatic Melanoma Cell Death. PLoS One. 2014; 9: e103762.

22. Merhi F, Tang R, Piedfer M, et al. Hyperforin Inhibits Akt1 Kinase Activity and Promotes Caspase-Mediated Apoptosis Involving Bad and Noxa Activation in Human Myeloid Tumor Cells. PLoS One. 2011; 6: e25963.

23. Martarelli D, Martarelli B, Pediconi D, et al. Hypericum Perforatum Methanolic Extract Inhibits Growth of Human Prostatic Carcinoma Cell Line Orthotopically Implanted in Nude Mice. Cancer Lett. 2004; 210: 27-33.

24. Di Carlo G, Nuzzo I, Capasso R, et al. Modulation of apoptosis in mice treated with Echinacea and St. John's wort. Pharmacol Res. 2003; 48: 272-7.

25. Jang $M H$, Lee $T H$, Shin MC, et al. Protective Effect of Hypericum Perforatum Linn (St. John's Wort) Against Hydrogen Peroxide-Induced Apoptosis on Human Neuroblastoma Cells. Neurosci Lett. 2002; 329: 17780.

26. Yegani AA, Istifli ES, Tekeli IO, Sakin F, Kaplan HM. Proapoptotic Effect of Hypericum perforatum (St. John's Wort) Extract in Human Colorectal Adenocarcinoma Cell Line HT29. Int J Pharmacol. 2020; 16: 120-5. 